\title{
Aplikasi Inventarisasi Aset Berbasis Web Dengan Metode Waterfall
}

\author{
Sanjaya Pinem¹, Victor Maruli Pakpahan² \\ ${ }^{1}$ Program Studi Teknik Informatika, Universitas Efarina, Jl. Pdt Wismar Saragih No. 1, Indonesia, 21142 \\ e-mail: ${ }^{1}$ pinemsanjaya@gmail.com, ${ }^{2}$ victor.pakpahan@gmail.com
}

Submitted Date: June $24^{\text {th }}, 2020$

Revised Date: June $27^{\text {th }}, 2020$
Reviewed Date: June $26^{\text {th }}, 2020$

Accepted Date: June $30^{\text {th }}$, 2020

\begin{abstract}
Asset inventory management in SMP Negeri 3 Tanah Jawa, Simalungun Regency, still uses the Microsoft Excel application and manual recording. This causes the data collection to be complicated or difficult to manage because the recording is only done on paper and stored in a file cabinet so it is very difficult to see and report data that has been long. As a result, reporting of goods entering and leaving goods occurs an error and is late. This problem was overcome by designing web-based applications. Applications are built using the waterfall method, starting with data collection through observation and interviews, analyzing system requirements to be evaluated based on system testing. Through this application, the process of recording and reporting asset variation can be accessed easily and in an organized manner.
\end{abstract}

Keywords: application; inventory; waterfall-method

\begin{abstract}
Abstrak
Pengelolaan inventarisasi aset di SMP Negeri 3 Tanah Jawa Kabupaten Simalungun, masih menggunakan aplikasi Microsoft Excel dan pencatatan secara manual. Hal ini mengakibatkan pendataan barang menjadi rumit atau susah untuk dikelola karena pencatatan hanya dilakukan di atas kertas dan disimpan dalam lemari berkas sehingga sangat sulit untuk melihat dan melaporkan data yang sudah lama. Akibatnya pelaporan barang yang masuk dan barang keluar terjadinya kesalahan dan terlambat. Permasalahan ini di atasi dengan merancang aplikasi berbasis web. Aplikasi yang dibangun menggunakan metode waterfall, dimulai dengan pengumpulan data melalui observasi dan interview, analisa kebutuhan sistem hingga dilakukan evaluasi berdasarkan pengujian sistem. Melalui aplikasi ini, proses pencatatan dan pelaporan inventariasi aset dapat diakses dengan mudah dan terorganisir.
\end{abstract}

Kata kunci: sistem informasi; inventarisasi; waterfall-method.

\section{Pendahuluan}

Inventarisasi merupakan kegiatan pencatatan atau penyusunan data barang yang dimiliki oleh institusi. Inventarisasi yang baik akan mendukung kelancaran operasional atau kegiatan yang telah dirancang sebelumnya. Dunia pendidikan saat ini dituntut memiliki inventarisasi yang baik terutama terhadap sarana dan prasarana penunjang untuk kelancaran kegiatan pendidika (Novita, 2017). SMP Negeri 3 Tanah Jawa dalam proses administrasi dan manajemen sudah terkomputerisasi, tetapi terbatas pada pencatatan data inventaris sekolah seperti meja, kursi, papan tulis, LCD proyektor, AC, UPS, dan alat-alat praktikum dan mengetik laporan-laporan lainya. Penggunaan aplikasi yang ada, belum memiliki sistem terintegrasi dalam pengolahan data sehingga keterlambatan dan kesalahan dalam inventarisasi sering muncul. Hal ini mengakibatkan diperlukannya suatu sistem yang menggunakan program khusus terintegrasi untuk pengolahan dan pemasukan data yang meliputi data inventaris alat dan bahan, data laporan kegiatan dan perawatan barangbarang sekolah.

\section{$2 \quad$ Landasan Teori}

Dalam menunjang pembahasan dalam pembahasan publikasi ini, penulis menjabarkan kerangka berpikir yang sering dipakai. Berikut adalah teori dasar yang dipakai dalam penelitian ini. 
a. Sistem informasi

Penggunaan sistem informasi di dalam sebuah organisasi mengumpulkan berbagai kebutuhan pengolahan data transaksi setiap hari serta mendukung fungsi organisasi yang sifatnya manajerial didalam aktivitasnya strategi dari sebuah organisasi supaya dapat menyediakan kepada pihak-pihak tertentu diluar dengan bermacam-macam laporan yang dibutuhkan (Sutabri, 2012).

b. Inventarisasi aset

Inventarisasi asset merupakan serangkaian kegiatan untuk melakukan pendataan, pencatatan, pelaporan hasil pendataan aset, dan mendokumentasikannya baik aset berwujud maupun aset tidak berwujud pada suatu waktu tertentu. Inventarisasi aset dilakukan untuk mendapatkan data seluruh aset yang dimliki, dikuasai sebuah organisasi perusahaan atau instansi pemerintah.(Gima, 2013)

Dari beberapa pendapat tersebut, dapat disimpulkan Sistem Informasi Inventaris adalah sebuah sistem yang mengolah transaksi dalam bentuk pendataan aset yang berwujud ataupun aset yang tidak berwujud pada suatu periode tertentu dalam suatu organisasi.

c. Kajian Pustaka

Penelitian yang dilakukan oleh Victor Marudut Mulia Siregar (2018) yang berjudul "Perancangan Sistem Informasi Inventaris Barang Pada Sekolah SMA Negeri 4 Pematangsiantar", menyimpulkan bahwa dengan adanya sistem informasi inventaris, maka pengolahan dan pencarian inventaris barang dapat dilakukan dengan cepat dan akurat (Siregar, 2018).

Penelitian yang dilakukan oleh Muhamad Bakhar (2019) yang berjudul "Sistem Informasi Inventaris dan Perawatan Sarana Prasarana di Politeknik Harapan Bersama", menyimpulkan bahwa dengan adanya sistem informasi inventaris dan perawatan sarana dan prasarana dapat meminimalisir kesalahan dalam pendataan aset(Bakhar, 2019).

Penelitian yang dilakukan oleh Diki Susandi dan Sukisno (2018) menyimpulkan bahwa dengan adanya sistem informasi inventaris, keterlambatan penyediaan sarana dapat dikurangi (Susandi \& Sukisno, 2018).

Penelitian yang dilakukan oleh Heri Kuswara dan Mikhael Ferdika (2017) yang berjudul "Sistem Informasi Penjualan Berbasis Web Pada PT Era Makmur Cahaya Damai Bekasi" menyimpulkan bahwa dengan adanya sistem informasi penjualan dengan metode waterfall dapat meningkatkan promosi dan pendapatan untuk PT Era Makmur Cahaya Damai (Ferdika \& Heri, 2016).

\section{Metodologi Penelitian}

Dalam metode pengembangan sistem, penulis menggunakan metode waterfall. Penulis memilih metode waterfall karena langkahlangkah pembuatan sistem yang teratur dan terukur. Untuk lebih lengkapnya metodologi penelitian berikut ini dapat dilihat pada Gambar 1.

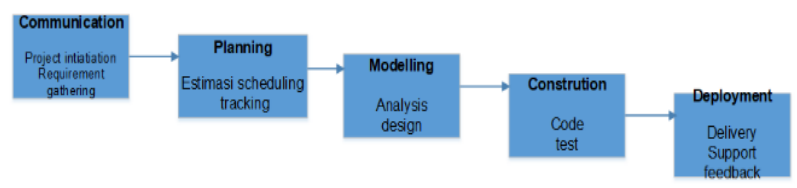

Gambar 1. Metode Waterfall

Metode waterfall ini mempunyai tahapan seperti yan ada di bawah ini:

1. Analisis Kebutuhan

Kendala dan tujuan dipenuhi pada tahap ini, hasil yang didapat dari pengguna dirincikan dan dibuat sebagai defenisi sistem.

2. Perancangan Sistem

Pada tahap ini dikumpulkan kebutuhan yang harus dipenuhi baik itu perangkat keras maupun perangkat lunak, dan juga pada tahapan ini dibentuk arsitektur dari keseluruhan sistem yang akan di implementasikan.

3. Implementasi

Hasil rancangan yang sudah dibangun pada tahap sebelumnya, dituangkan dalam bentuk implementasi dari setiap unit program membentuk sebuah sistem yang satu.

4. Testing (Pengujian)

Tahap ini unit program diuji dan digabung dan diverifikasi untuk menguji apakah sesuai dengan kebutuhan yang dikumpulkan sebelumnya (Pressman \& Maxim, 2015).

Analisis kebutuhan sistem didapat dari observasi dan wawancara yang langsung berkomunikasi dengan Kepala Sekolah SMP 
Negeri 3 Tanah Jawa Kabupaten Simalungun. Perancangan sistem dilakukan dengan menggunakan UML (Unified Modeling Language) yang tahapan didalamnya terdiri Use Case diagram, Activity diagram, Sequency diagram, Class diagram. Dan untuk implementasi dilakukan dengan menggunakan bahasa pemrograman PHP yang dibantu dengan Xampp Webserver.

Untuk pengujian dilakukan oleh blackbox, Black-box merupakan pengujian perilaku perangkat lunak yang menitikberatkan pada kebutuhan fungsional perangkat lunak(Salamah \& Khasanah, 2017). Teknik pengujian black-box yang berfokus kepada proses input dan output untuk memeriksa apakah program tersebut sesuai dengan hasil yang diharapkan (Ningrum, Suherman, Aryanti, Prasetya, \& Saifudin, 2019).

\section{Hasil dan Pembahasan}

\subsection{Analis kebutuhan sistem}

Analisis kebutuhan sistem didapatkan dari observasi dan wawancara di pada SMP Negeri 3 Tanah Jawa, Kab. Simalungun yang dapat dilihat dari Tabel 1 di bawah ini.

Tabel 1. Hasil Analisis Kebutuhan

\begin{tabular}{|l|l|}
\hline Activity & Functional Requirement \\
\hline $\begin{array}{l}\text { Mengelola } \\
\text { data inventaris }\end{array}$ & $\begin{array}{l}\text { Sistem yang dirancang harus } \\
\text { dapat menampilkan, mengubah, } \\
\text { dan menambah data invetaris }\end{array}$ \\
\hline $\begin{array}{l}\text { Mengelola } \\
\text { stok barang }\end{array}$ & $\begin{array}{l}\text { Sistem yang dirancang harus } \\
\text { dapat menampilkan dan } \\
\text { menambah stok barang }\end{array}$ \\
\hline $\begin{array}{l}\text { Mengelola } \\
\text { data barang } \\
\text { masuk }\end{array}$ & $\begin{array}{l}\text { Sistem yang dirancang harus } \\
\text { dapat menampilkan dan } \\
\text { menambah barang masuk }\end{array}$ \\
\hline $\begin{array}{l}\text { Mengelola } \\
\text { data barang } \\
\text { keluar }\end{array}$ & $\begin{array}{l}\text { Sistem yang dirancang harus } \\
\text { dapat menampilkan dan } \\
\text { menambah barang keluar }\end{array}$ \\
\hline $\begin{array}{l}\text { Mengelola } \\
\text { data pemakai }\end{array}$ & $\begin{array}{l}\text { Sistem yang dirancang harus } \\
\text { dapat menampilkan, merubah, } \\
\text { dan menghapus data pelanggan }\end{array}$ \\
\hline
\end{tabular}

Berdasarakan dari analisis kebutuhan fungsional dan analisis kebutuhan nonfungsional yang dilakukan, berupa kebutuhan hardware dan dan kebutuhan software seperti di bawah ini:

\section{Analisis Kebutuhan Hardware}

Kebutuhan hardware yang juga penting dalam penelitian ini terdiri dari beberapa komponen komputer diantaranya:
1) Processor intel ${ }^{\circledR}$ Celeron ${ }^{\circledR} \mathrm{CPU} N \mathrm{~N} 3060$ @ 1.60GHz;

2) Random Acces Memory $4.00 \mathrm{~GB}$;

3) Hard Disk 500 GB HDD.

\section{Analisis Kebutuhan Software}

Kebutuhan minimum pada software adalah:

1) Komputer terinstall windows 10 64bit;

2) XAMPP versi 3.2.2;

3) Database MYSQL 4.8.5.

\subsection{Analisis dengan Use Case Diagram}

Use Case Diagram mencirikan apa yang akan dilakukan oleh sistem, dan penulis mendeskripsikannya di Gambar 1. berikut ini:

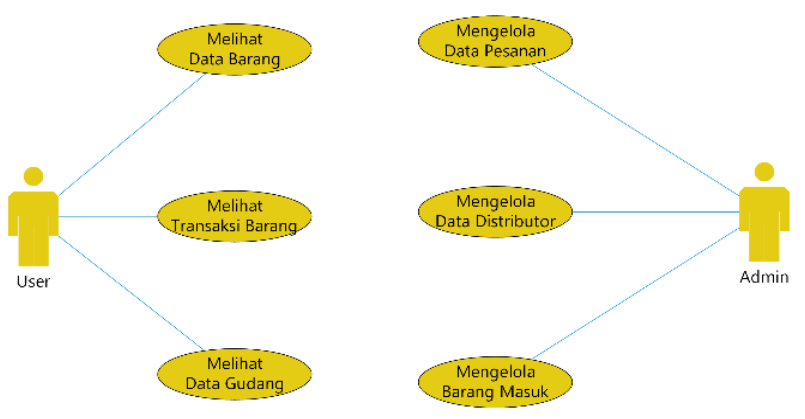

Gambar 1. Use Case Diagram

\subsection{Analisis menggunakan Activity Diagram}

Activity Diagram menggambar sebuah aktifitas yang terjadi dalam sebuah sistem informasi. Activity Diagram boleh berisikan satu buah use case atau beberapa di dalamnya.

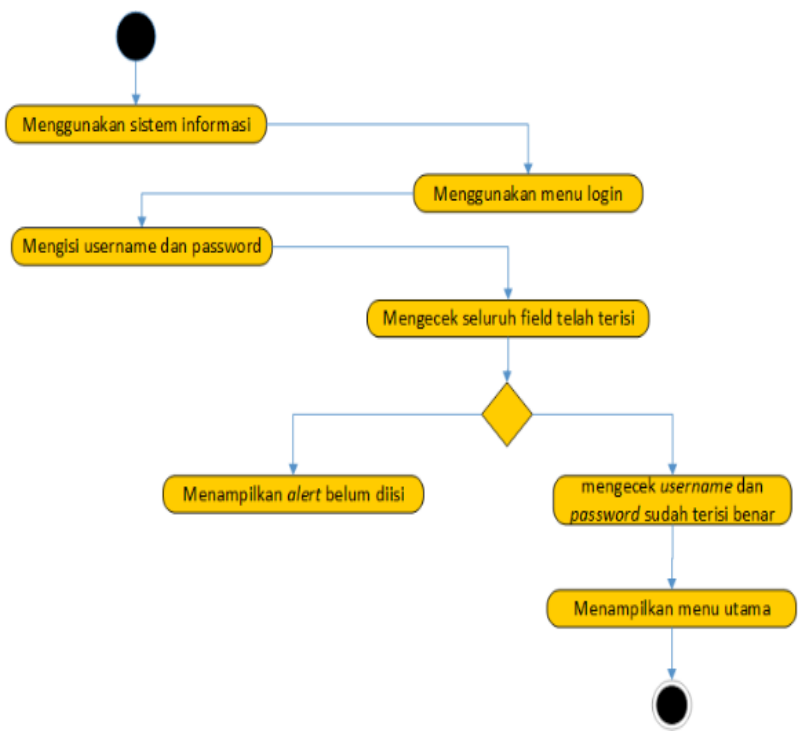

Gambar 2. Activity diagram menu utama 


\subsection{Analisis Database Sistem menggunakan} MySQL Server

Sistem informasi yang dibangun berdasarkan desain analisis database seperti di Tabel 2, 3 dan 4 di bawah ini:

Tabel 2. Database User

\begin{tabular}{|l|l|l|l|}
\hline No & Nama Field & Tipe Data & Keterangan \\
\hline 1 & Id & Int (11) & id \\
\hline 2 & Nik & varchar(100) & Primary Key \\
\hline 3 & nama & varchar(100) & Nama \\
\hline 4 & Alamat & varchar(100) & Alamat \\
\hline 5 & Telepon & Int (15) & Telepon \\
\hline 6 & Username & varchar(100) & Username \\
\hline 7 & Password & varchar(100) & Password \\
\hline 8 & Level & $\begin{array}{l}\text { Enum } \\
\text { ('admin', 'member') }\end{array}$ & $\begin{array}{l}\text { Level } \\
\text { pengguna }\end{array}$ \\
\hline
\end{tabular}

Tabel 3: Tabel Barang masuk

\begin{tabular}{|l|l|l|l|}
\hline No & Nama Field & Tipe Data & Keterangan \\
\hline 1 & Id & $\operatorname{int}(11)$ & Id \\
\hline 2 & Kode_barang & $\operatorname{varchar}(100)$ & Primary Key \\
\hline 3 & Nama_barang & Varchar(100) & Nama Barang \\
\hline 4 & Pengirim & varchar(100) & Pengirim \\
\hline 5 & Penerima & varchar(100) & Penerima \\
\hline 6 & Tanggal & Varchar $(100)$ & Tanggal \\
\hline 7 & Jumlah & Int(11) & Jumlah \\
\hline
\end{tabular}

Tabel 4: Tabel Gudang

\begin{tabular}{|l|l|l|l|}
\hline No & Nama Field & Tipe Data & Keterangan \\
\hline 1 & Id & $\operatorname{int}(11)$ & Id \\
\hline 2 & Kode_barang & $\operatorname{varchar}(100)$ & Primary Key \\
\hline 3 & Nama_barang & Varchar(100) & Nama Barang \\
\hline 4 & Pengirim & $\operatorname{varchar}(100)$ & Pengirim \\
\hline 5 & Penerima & $\operatorname{varchar}(100)$ & Penerima \\
\hline 6 & Tanggal & Varchar $(100)$ & Tanggal \\
\hline 7 & Jumlah & Int(11) & Jumlah \\
\hline
\end{tabular}

\subsection{Implementasi}

Implementasi

dilakukan dengan meggunakan admin lte sebagai antarmuka sistem, user dapat masuk ke dashboard setelah memasukkan username dan password di halaman login, seperti yang dapat dilihat dari Gambar 3 .

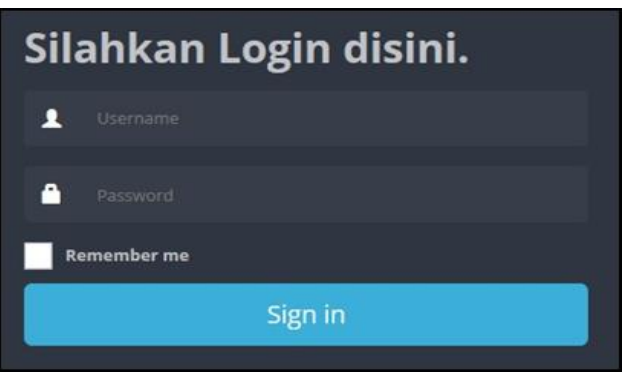

Gambar 3. Halaman Login

Setelah pengguna masuk ke dashboard, pengguna dapat langsung mengakses aset baik barang masuk maupun keluar seperti yang ditunjukkan oleh Gambar 4 dan Gambar 5.

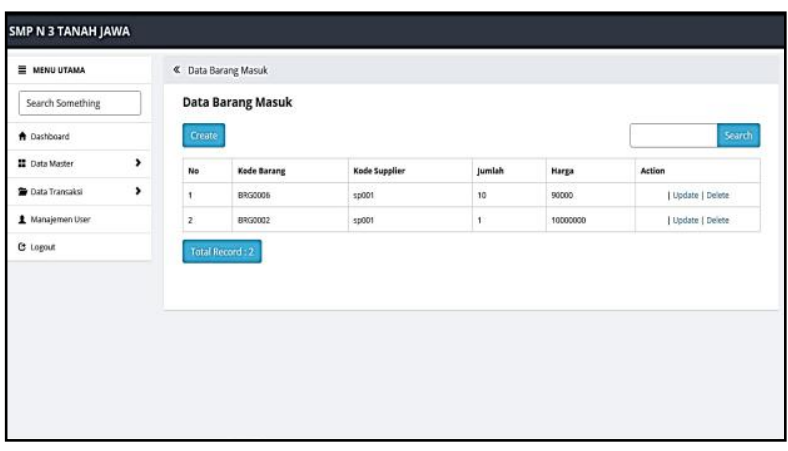

Gambar 4. Halaman Data Barang Masuk

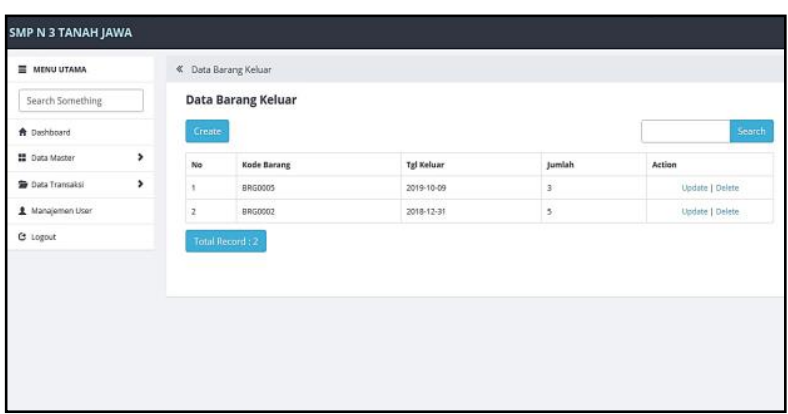

Gambar 5. Halaman Data Barang Keluar

Dan untuk menambah aset yang tambah dapat diakses di menu tambah barang masuk. Pengguna harus memasukkan semua informasi yang berkaitan tentang barang tersebut, diantaranya nama barang, harga, foto barang 
sebagai informasi, jenis barang, merk barang, nama supplier, dan stok. Untuk lebih jelasnya dapat dilihat dari Gambar 6 di bawah ini:

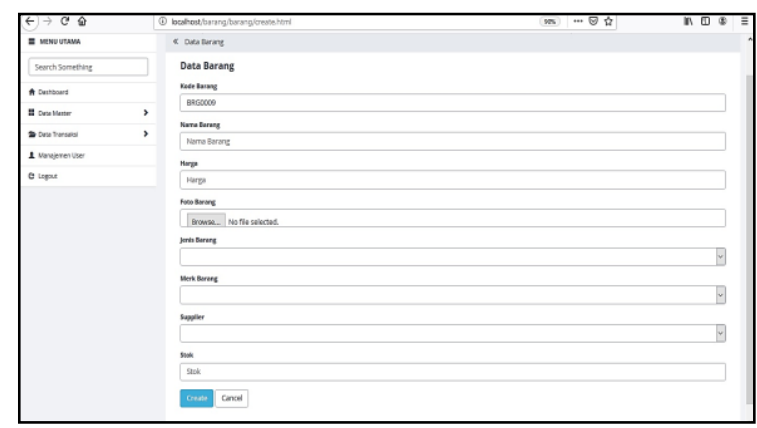

Gambar 6. Halaman Tambah Data Barang

\subsection{Black-box testing}

Penelitian ini menggunakan pengujian dengan black-box untuk melihat dan memastikan bahwa semua kebutuhan dari sistem telah tercukupkan sehingga menghasilkan keluaran yang diharapkan, pengujian black-box tersebut dapat dilihat dari Tabel 5 di bawah ini

Tabel 5. Pengujian dengan black-box

\begin{tabular}{|l|l|}
\hline $\begin{array}{l}\text { Nama } \\
\text { Kasus Uji }\end{array}$ & $\begin{array}{l}\text { Penambahan data barang masuk } \\
\text { berhasil. }\end{array}$ \\
\hline $\begin{array}{l}\text { Tujuan } \\
\text { Pengujian }\end{array}$ & $\begin{array}{l}\text { Menjamin bahwa sistem mampu } \\
\text { menyelesaikan proses penambahan } \\
\text { data barang masuk jika informasi } \\
\text { yang dibutuhkan lengkap. }\end{array}$ \\
\hline $\begin{array}{l}\text { Prosedur } \\
\text { Uji }\end{array}$ & $\begin{array}{l}\text { 1. Menekan tombol create pada } \\
\text { menu barang masuk } \\
\text { 2. Mengisi form tambah barang } \\
\text { masuk }\end{array}$ \\
\hline $\begin{array}{l}\text { Hasil yang } \\
\text { diharapkan }\end{array}$ & $\begin{array}{l}\text { Penyimpanan data barang masuk ke } \\
\text { dalam database dapat dilakukan } \\
\text { sistem }\end{array}$ \\
\hline $\begin{array}{l}\text { Hasil } \\
\text { Pengujian }\end{array}$ & $\begin{array}{l}\text { Penyimpanan data barang masuk ke } \\
\text { dalam database dapat dilakukan } \\
\text { sistem }\end{array}$ \\
\hline Status & Valid \\
\hline
\end{tabular}

\section{Kesimpulan}

Berdasarkan observasi dan wawancara yang dilakukan, penelitian ini menghasilkan sistem informasi yang dibutuhkan, perancangan yang dilakukan secara terstruktur dengan menggunakan Use Case Diagram dan Activity Diagram. Sistem informasi ini merupakan aplikasi web-based, sehingga memudahkan pengguna untuk dapat mengaksesnya dimana saja. Dengan adanya sistem informasi ini, pengolahan dan pencatatan data inventarisasi dapat mudah digunakan oleh pengguna.

\section{Referensi}

Bakhar, M. (2019). Sistem Informasi Inventaris dan Perawatan Sarana Prasarana di Politeknik Harapan Bersama. Syntax Literate; Jurnal Ilmiah Indonesia, 4(8), 94-107.

Ferdika, M., \& Heri, K. (2016). Sistem Informasi Penjualan Berbasis Web Pada PT. Cahaya. Jurnal Ilmiah Teknologi Informasi Asia, 10(2), $1-16$.

Gima, S. (2013). Manajemen Aset Pariwisata. Bandung: Guardaya Intimarta.

Ningrum, F. C., Suherman, D., Aryanti, S., Prasetya, H. A., \& Saifudin, A. (2019). Pengujian Black Box pada Aplikasi Sistem Seleksi Sales Terbaik Menggunakan Teknik Equivalence Partitions. Jurnal Informatika Universitas Pamulang, 4(4), 125.

https://doi.org/10.32493/informatika.v4i4.3782

Novita, M. (2017). Sarana Dan Prasarana Yang Baik Menjadi Bagian Ujung Tombak Keberhasilan Lembaga Pendidikan Islam. NUR EL-ISLAM: Jurnal Pendidikan Dan Sosial Keagamaan, Volume 4,(2), 127. Retrieved from http://ejournal.staiyasnibungo.ac.id/index.php/n urelislam\%0Ahttp://moraref.or.id/record/view/ 64714

Pressman, R. S., \& Maxim, B. R. (2015). Software Engineering : A Practitioner's Approach, Eighth Edition. ACM SIGSOFT Software Engineering Notes.

https://doi.org/10.1145/1226816.1226822

Salamah, U., \& Khasanah, F. (2017). Pengujian Sistem Informasi Penjualan Undangan Pernikahan Online Berbasis Web Menggunakan Black Box Testing. Information Management for Educators and Professionals, 2(1), 35-46.

Siregar, V. M. M. (2018). Perancangan Sistem Informasi Inventaris Barang Pada Sekolah SMA Negeri 4 Pematangsiantar. It Journal Research and Development, 3(1), 54-61. https://doi.org/10.25299/itjrd.2018.vol3(1).189 9

Susandi, D., \& Sukisno, S. (2018). Sistem Informasi Inventaris Berbasis Web di Akademi Kebidanan Bina Husada Serang. JSiI (Jurnal Sistem Informasi), 5(2), 46-50. https://doi.org/10.30656/jsii.v5i2.775

Sutabri, T. (2012). Analisis Sistem Informasi. In Analisa Sistem Informasi. 